Eva Brosch, Carmen Binnewies*

\title{
A Diary Study on Predictors of the Work-life Interface: The Role of Time Pressure, Psychological Climate and Positive Affective States
}

\begin{abstract}
The present diary study builds upon the work-home resources model (ten Brummelhuis \& Bakker, 2012) and the Model of Work-Family Enrichment (Greenhaus $\&$ Powell, 2006), and examines time pressure and psychological climate as predictors of work-life conflict and work-life enrichment. We further investigated happiness and vigour as indicators of positive mood and energy as mediators in these associations. Our five-day diary study was conducted via electronic devices with 92 employees ( $\mathrm{N}=357$ matched daily measurements). We assessed daily time pressure, psychological climate, job control (as control variable), happiness, and vigour at work at the end of the working day. In the evening survey, answered before going to bed, we assessed daily work-life conflict and work-life enrichment. Results of nested multilevel path models, controlled for daily job control, revealed that daily time pressure was related to increased work-life conflict and decreased work-life enrichment. Daily psychological climate was negatively related to work-life conflict and positively related to work-life enrichment. Mediation analyses proved an energypath. Vigour mediated the confirmed relations while happiness was no mediator.
\end{abstract}

Keywords: work-life balance, work-life conflict, managing work demands, work resources (JEL-Codes: C83, C93, I19, J81)

\section{Introduction}

Today, many employees face problems balancing work and other life domains (Chen, Powell, \& Cui, 2014; Mauno et al., 2015; Voydanoff, 2005). Traditionally men used to be the breadwinner in the family and women were concerned with the household. Nowadays, more and more often both men and women work to support the family (Gatrell, Burnett, Cooper, \& Sparrow, 2013) and therefore both have to deal with issues regarding the work-life interface. Work-life balance can be understood as low work-life conflict and high work-life enrichment (Mauno \& Ratanen, 2013). Work-life conflict arises when work requires a greater amount of resources than an employee wishes to allocate to work. Work-life enrichment is ex-

* Eva Brosch, Prof. Dr.; Carmen Binnewies, University of Muenster, Institute for Psychology, Fliednerstr. 21, 48159 Münster, Germany. E-mail: eva.brosch@uni-muenster.de.

** Article received: January 31, 2017

Article accepted: November 21, 2017

mrev, 29 (1) 2018, $55-78$ 
perienced when work has a positive impact on other life domains by requiring fewer resources than expected or when resources from the work domain positively impact other life domains (Grawitch \& Barber, 2010).

In this article, we examine how time pressure and psychological climate are related to work-life conflict and enrichment. Ten Brummelhuis and Bakker (2012) propose in their work-home resources model, that both work demands and work resources are related to home outcomes and that these relationships are mediated by personal resources. We studied time pressure as an indicator of quantitative work demands/ workload which is considered as one of the most important work demands in theory (Karasek, 1979) and has also been shown to be relevant for the work-life interface (Michel, Kotrba, Mitchelson, Clark, \& Baltes, 2011). In addition, we focused on psychological climate as an indicator for social resources of the workplace which are considered to be very prominent and powerful resources at work (Halbesleben, 2006; Melamed, Kushnir, \& Meir, 1991). In this study, we are particularly interested in predicting the daily experience of the work-life interface by daily changes of time pressure and psychological climate. Day-specific time pressure refers to the incongruity of work tasks and time available on a particular day. In line with Xanthopoulou, Bakker, Demerouti, and Schaufeli (2012) we refer to psychological climate as the component of work group cooperation, friendliness and warmth (Jones $\&$ James, 1979). Experiencing a high level of psychological climate on a given day means experiencing a high level of cooperation and warmth within the work team (Xanthopoulou et al., 2012). We propose that daily time pressure increases daily work-life conflict and decreases daily work-life enrichment, while we will argue that daily psychological climate at work mitigates work-life conflict and augments worklife enrichment.

In addition, we will shed light on the explaining mediating mechanisms. Drawing on the Model of Work-Family Enrichment (Greenhaus \& Powell, 2006) we propose two affective paths, the mood-path and the energy-path, as mediators between the work and the life domains. The mood-path represents hedonic well-being (Ryan \& Deci, 2001). We examined happiness as an indicator of hedonic well-being. The affective state of happiness is defined as experiencing pleasant, positive emotions as described in the broaden-and-build theory by Fredrickson (1998). The energy-path represents eudaimonic well-being (Ryan \& Deci, 2001). We investigated vigour as an indicator of eudaimonic well-being, which can also be seen as an indicator of self-regulatory resources (Baumeister, Heatherton, \& Tice, 1994)

Our study extends the existing literature in several ways. First, by applying a daily diary study design (Ohly, Sonnentag, Niessen, \& Zapf, 2010), we capture daily dynamics in demands and resources in association with daily work-life conflict and enrichment. As work-life conflict and enrichment substantially differ from day to day (Butler, Grzywacz, Bass, \& Linney, 2005), we are interested in identifying work-related predictors of these daily differences within persons. This knowledge 
can help us in developing and improving work-related interventions, such as workplace design or individual training programs to help employees balancing their work and private life.

Second, although the work-home resources model suggests both positive and negative home outcomes (ten Brummelhuis \& Bakker, 2012), most studies focused only on either the conflicting (e. g. Parasuraman \& Simmers, 2001; Seiger \& Wiese, 2009) or the enriching mechanism (e. g. Daniel \& Sonnentag, 2014; McNall, Scott, \& Nicklin, 2015) of the work-home process. Consequently, we extend the existing literature by studying both mechanisms: work-life conflict and work-life enrichment.

Third, we extend the existing literature by focusing on a broader conceptualization of the life and home domain and not only on the family domain. According to Eurostat (2016), about $30 \%$ of the households in the European Union were singleperson households in 2010. In the US, about $35 \%$ of the households are nonfamily households (family household: married couple or a family with children; United States Census Bureau, 2015). Even if employees have a family, they may hold further important roles and responsibilities (e. g. volunteer work, sport-team member) that impact their experience of work-life conflict and enrichment. We take the perspective that processes are not limited to persons living together with a family but may also include further life domains (Fisher, Bulger \& Smith, 2009). Consequently, we focused on work-life conflict and enrichment rather than on work-family conflict and enrichment.

\section{Work-Life Conflict and Work-Life Enrichment}

Both conflict and enrichment between life domains can be conceptualized bidirectionally, i. e. from work to life and vice versa (Mauno \& Rantanen, 2013, Michel et al., 2011). In our study, we are interested how the work domain affects the home domain, and therefore focus on conflict and enrichment from work to the home domain.

There are different conceptualizations of the characteristics of the interface. The most prominent research area encompasses the work-family interface. Mostly the terms work-family conflict and work-family enrichment are used to describe the mechanisms between the two domains (Greenhaus \& Powell, 2006; Mauno et al., 2015; Mauno \& Rantanen, 2013; McNall et al., 2015; Moazami-Goodarzi, Nurmi, Mauno, \& Rantanen, 2015). However, as the work-home interface is not limited to persons living together with a family (Fisher et al., 2009), we follow Daniel and Sonnentag (2014) terming the mechanisms work-life conflict and work-life enrichment.

Extending the prominent family-focused definition by Greenhaus and Beutell (1985), we refer to Keeney, Boyd, Sinha, Westring, and Ryan (2013) who describe 
work-life conflict as the 'difficulty participating in nonwork domains by virtue of participation in the work domain' (p. 222). Work-life conflict is a transmission of demands and consequent strain from one life domain to the other (Bakker, Demerouti, \& Dollard, 2008). Moreover, involvement in the work role can produce positive outcomes in the home domain (Voydanoff, 2001). Greenhaus and Powell (2006) define work-family-enrichment as 'the extent to which experiences in one role improve the quality of life in another role' (p. 73). Employees experience worklife enrichment when work has a positive contribution to the home domain by requiring fewer resources than expected or when resources expended at work have a positive contribution to the home domain (Grawitch \& Barber, 2010).

To provide a broader picture of the work-home interface, we want to study both conflict and enrichment as both low levels of work-life conflict, and high levels of work-life enrichment are characteristic for a positive work-life balance (Mauno \& Ratanen 2013). Work-life conflict and work-life enrichment are similar but distinct constructs (Fisher et al., 2009). Employees who do not experience conflict, do not automatically experience an enrichment of their private life.

Developing our research model, we draw on the work-home resources model (ten Brummelhuis \& Bakker, 2012). According to the model both work demands and work resources are related to the home outcomes, work-life conflict and work-life enrichment and these relationships are mediated by affective well-being (Greenhaus $\&$ Powell, 2006). In the following, we will first provide a theoretical framework for our study model before we derive the hypotheses in the next section.

Spillover processes between daily work characteristics and work-life conflict/worklife enrichment can be explained by two dimensions of affective well-being, namely hedonic and eudaimonic well-being (Ryan \& Deci, 2001). Hedonic well-being refers to happiness in terms of pleasure attainment and pain avoidance. In line with this view, we conceptualized happiness as an indicator of hedonic well-being. The affective state of happiness represents pleasant, positive emotions as described in the broaden-and-build theory by Fredrickson (1998). Eudaimonic well-being involves well-being in terms of the degree to which a person is fully functioning and can be seen as an indicator of self-regulatory resources (Baumeister et al., 1994). The affective state of vigour - sometimes called vitality - is a common indicator of eudaimonic well-being (Ryan \& Deci, 2001). Both hedonic and eudaimonic well-being have been shown to be relevant for various outcomes such as job satisfaction and personal initiative (Hahn, Frese, Binnewies \& Schmitt, 2012; Martínez-Martí \& Ruch, 2017). Concerning our theoretical model, we argue that happiness (moodpath) and vigour (energy-path) mediate the relationships between work characteristics and work-life conflict and work-life enrichment.

Concerning the mood path, we will first explain why work characteristics are related to happiness and why happiness is related to work-life conflict and enrichment. Work resources, especially social resources as psychological climate, are perceived as 
positive experiences and are therefore predictors of affective well-being (Fredrickson, 1998). According to Fredrickson's (1998) broaden-and-build theory, the hedonic state of happiness broadens an employees' momentary thought-action repertoire and builds resources such as physical, intellectual and social skills (Fredrickson, 1998). The built-up resources, in turn, should benefit employees' engagement in private life. Applied to our study, we argue that, on days, when an employee experiences a higher level of psychological climate at work, he/she leaves work happier and is better able to deal with demands at home and can benefit from the positive mood in the life domain. When an employee experiences a higher level of job demands on a given day than on other days, he/she leaves work with more negative feelings. Consequently, the momentary thought-action repertoire is diminished (Fredrickson, 1998), and engagement in private life is attenuated (ten Brummelhuis \& Bakker, 2012).

The energy-path conceptualizes vigour, an indicator of eudaimonic well-being, as the mediating mechanism between work characteristics and home outcomes. The limited resources view of self-regulation provides an explanation of this mechanism. Self-regulation is a limited, depletable resource and is assumed to behave like a muscle' (Muraven \& Baumeister, 2000, p. 247) meaning that the regulation of behaviour requires energy, which gets depleted by effort. The conceptualization of selfregulation as limited resource implies that when self-regulation has been invested, subsequent self-regulation will suffer (Muraven \& Baumeister, 2000). Consequently, we argue that on days when an employee experiences a high level of job demands, an employee's self-regulatory resources are more exhausted, and therefore he/she lacks energy for the engagement in private life and is more likely to experience work-life conflict. On days when an employee experiences psychological climate at work, self-regulatory resources should be less exhausted, engagement in private life should be easier, and an employee should be more likely to experience higher work-life enrichment. In the next section, we will derive the hypotheses, first concerning time pressure as a prominent work demand, then concerning psychological climate as an important work resource.

\section{Time Pressure as a Demand in the Work-home Interface}

Job demands require sustained physical and/or psychological (i. e. cognitive and emotional) effort and are therefore associated with psychological and physical costs. On days, when having to deal with many job demands, employees use up more of their energy resources (Meijman \& Mulder, 1998), which in turn are lacking in the home domain. In our study, we focus on time pressure as daily work demand.

Time pressure, as the incongruity of the amount of work an employee is expected to accomplish during the time available (Höge, 2009), is one of the most prominent work demands. The similar concept of work role overload resulted in the strongest work stressor among others predicting work-family conflict in a meta-analysis by 
Michel et al. (2011). Day-specific time pressure refers to the incongruity of work tasks and time available on a particular day. Dealing with a high level of time pressure on a given day requires self-regulation resources. Therefore, employees feel strained when leaving work (Butler et al., 2005; Karasek, 1979). Referencing to the energy-path, we argue that on work days with a high level of time pressure, energy resources are depleted by the work tasks and then are lacking in the evening when dealing with home demands. Concerning the mood-path, we argue that not being able to get the work done, leaves the employee with unpleasant feelings after work. This leads to negative home situations as employees keep thinking about work and cannot enjoy the company of their partner. Prior research showed that social undermining behaviours, as well as a reduction of the involvement in family life, can be consequences (Bakker et al., 2008). As such, conflicts evoke caused by the demands at work. Going beyond the propositions of the demand-control model (Karasek, 1979), we believe that the model may be extended in a way that it makes not only propositions about negative home outcomes but also about enrichment (Butler et al., 2005). Coming home after a demanding day at work, employees feel less enriched because work required resources which then are lacking at home (Grawitch $\&$ Barber, 2010). Applying these assumptions to the work-home resources model, we propose that the work demand time pressure is negatively related to happiness (mood-path) and vigour (energy-path) and that these, in turn, are related to both work-life conflict and work-life enrichment.

Hypothesis 1: Daily time pressure at work is positively related to daily work-life conflict.

Hypothesis 2: Daily time pressure at work is negatively related to daily work-life enrichment.

Hypothesis 3: The relationship between daily time pressure at work and a) daily worklife conflict as well as b) daily work-life enrichment is mediated by daily after-work happiness.

Hypothesis 4: The relationship between daily time pressure at work and a) daily worklife conflict as well as b) daily work-life enrichment is mediated by daily after-work vigour.

\section{Psychological Climate as a Resource in the Work-home Interface}

Climate can be regarded as an organizational attribute and as an individual attribute (James \& Jones, 1974). Psychological climate is an individual perception of the work environment (Jones \& James, 1979). In line with Xanthopoulou et al. (2012), we focus on the component of work group cooperation, friendliness and warmth (Jones \& James, 1979). In this sense, psychological climate refers to the perception of the workgroup and represents the social environment at work (Demerouti, Kat- 
tenbach, \& Nachreiner, 2003). Experiencing a high level of psychological climate on a given day means experiencing a high level of cooperation and warmth within the work team (Xanthopoulou et al., 2012). Psychological climate is stable to a certain degree, but even if employees in general experience a positive team spirit, the experience of this climate also fluctuates from day to day (Kühnel, Sonnentag, \& Bledow, 2012; Xanthopoulou, Bakker, Demerouti, \& Schaufeli, 2009; Xanthopoulou et al., 2012). As such, we propose that psychological climate works as a resource in the work-home resources model. With regard to the model, we hypothesize that psychological climate is related to work-life conflict and work-life enrichment and that these relationships are mediated by the mood path and the energy path.

Psychological climate fulfils the basic human need of relatedness (Deci \& Ryan, 1985) and should, therefore, play a motivational role at work. Being motivated at work, employees feel energetic, accomplish more at work and they feel happier (Scott, Colquitt, Paddock, \& Judge, 2010). When experiencing a positive psychological climate at work, employees are not distracted by conflicts with their colleagues. Self-regulation resources are not used up for dispelling arguments but can be capitalized to maintain on task focus (Beal, Weiss, Barros, \& MacDermid, 2005). After a day at work when an employee experienced a high level of psychological climate and thus no conflicts at work, employees have less reason to think about work in the after-hours. When employees experience less psychological climate at work, they are caught up with work-related thoughts and use up self-regulatory resources on work even in the after-hours. Consequently, it is difficult to engage in family life or pursue hobbies. Thus, work and private life are not balanced.

Experiencing a high level of psychological climate at work, employees feel happier and more vigorous after work (Scott et al., 2010). Considering the mood-path, coming home in a good mood, the positive affective state crosses over to the partner (Bakker et al., 2008) resulting in a pleasant atmosphere at home. Concerning the energy-path, employees handle daily hassles more serene when their energy resources are not exhausted due to their job. The home domain is enriched by the work domain.

In line with these assumptions and the work-home resources model (ten Brummelhuis \& Bakker, 2012), we hypothesize that psychological climate is positively related to happiness and vigour and that these positive affective states are related to work-life conflict and work-life enrichment.

Hypothesis 5: Daily psychological climate is negatively related to daily work-life conflict.

Hypothesis 6: Daily psychological climate is positively related to daily work-life enrichment. 
Hypothesis 7: The relationship between daily psychological climate at work and a) daily work-life conflict as well as b) daily work-life enrichment is mediated by daily after-work happiness.

Hypothesis 8: The relationship between daily psychological climate at work and a) daily work-life conflict as well as b) daily work-life enrichment is mediated by daily after-work vigour.

\section{The Role of Job Control}

Job control refers to the freedom to decide what to do at work and how to do it (Semmer, Zapf, \& Dunckel, 1999). Job control is considered to be one of the most important work characteristics (e. g. Hackman \& Oldham, 1976) because it fulfils the basic human needs of autonomy and competence (Deci \& Ryan, 1985). Karasek (1979) stressed the importance of job control for reducing job-related strain. As strain produced at work makes it difficult to fulfil requirements at home (Greenhaus \& Beutell, 1985), a low level of daily job control should result in drained energy resources. Coming home, employees lack resources for their daily routines and consequently should experience a greater work-life conflict. Recently, though, job control is discussed to have both sourcing and straining aspects (Langfred \& Moye, 2004). Schaufeli and Taris (2014) suggest that resources like job control may also be experienced negatively. Consequently, job control may augment work-life conflict and diminish work-life enrichment. In our study, we decided to include job control as a control variable.

\section{Method}

\section{Procedure and Participants}

We conducted a daily diary study implementing a within-person design. Participants took part in a five-day diary study with three measurement points: in the morning before going to work, in the afternoon right after work, and in the evening before going to bed. The results in this paper are based on only two daily measurement points: after work and before going to bed. Data for the study were collected in seven German municipal administrations. A total of 107 persons agreed to take part in this study which equals a response rate of about three percent. Participants were asked to complete a general survey first and then received portable devices with touch screen providing the daily surveys. Seven participants took part in the study with their own Smartphone. This was possible if the phone met the technical requirements. Data included time stamps when participants answered the survey. Therefore, we were able to check if the survey was filled out according to instructions. In total, participants answered 484 after work surveys and 470 evening surveys. On average participants spent about 8 minutes on both questionnaires. Due to non-compliance (e. g. participants filled out the after work surveys the next 
morning, or they filled out both surveys at the same time) five participants were excluded from analysis. Due to missing data (because either the after-work survey or the survey before going to bed was missing) another two participants had to be excluded. We further excluded eight participants from the analysis, because they provided only one complete day. With only one complete day we cannot make any statement about within-person variance. Overall, our final sample included 357 days by 92 persons. On average each person provided complete data of 3.88 days. Of the final sample, $57.6 \%$ were female, and $42.4 \%$ were male. The average age was 46.00 years $(S D=10.53$ ) with a range of 24 to 63 years. $27 \%$ held supervisory positions, and $86 \%$ indicated they worked full time (38.5 - 41 hours per week). On average participants had 22.6 years of work experience and worked for 7.8 years at the current workplace. Most of the participants worked in administration (e. g. civil servant, clerk), about $14 \%$ worked in the field of construction, architecture, and measurement (e. g. construction engineer), about $14 \%$ worked in the social or educational sector (e. g. social worker), and about six percent worked in the IT sector (e. g. IT specialist). Concerning their private life, $78 \%$ of the participants lived with a partner, and $36 \%$ of the participants had children.

\section{Measures}

All scales were presented in German and were answered on a five-point Likert-scale ranging from 1 (not at all) to 5 (very much), except for the demographic variables. We analysed the reliability for each workday separately.

Daily work-life enrichment. Daily work-life enrichment was measured with three items from the measure of work/nonwork interference and enhancement by Fisher et al. (2009). We adapted the items to day level context. A sample item is 'Things I did at work helped me to deal with personal and practical issues at home.' Daily work-life enrichment was assessed in the evening survey. Over the five days, the average internal consistency was .78 (range between .66 and .84).

Daily work-life conflict. Daily work-life conflict was measured with five items from the measure of work/nonwork interference and enhancement by Fisher et al. (2009). We adapted the items to day level context. A sample Item is 'My personal life suffered today because of my work.' Daily work-life conflict was assessed in the evening survey. Over the five days, the average internal consistency was .90 (range between .88 and .93).

Daily psychological climate. Daily psychological climate was measured with three items. Two items were developed by Demerouti et al. (2003). The third item was developed by Kühnel et al. (2012) to avoid potential problems with a two-item scale. One sample item is 'Today, there was a very good working atmosphere.' Daily psychological climate was assessed in the survey after work. Over the five days, the average internal consistency was .92 (range between .89 and .95). 
Daily job control. Daily job control was measured with four items developed by Semmer (1984) and Zapf (1993). This scale is used in German-speaking countries (Sonnentag, 2003). One sample item is 'Today I could determine in which way I do my work.' Daily job control was assessed in the survey after work. Over the five days, the average internal consistency was .86 (range between .79 and .93).

Daily time pressure. Daily time pressure was measured with three items developed by Semmer (1984) and Zapf (1993). This scale is widely used in German-speaking countries (Frese, 1985; Garst, Frese, \& Molenaar, 2000; Semmer, Zapf, \& Greif, 1996, Sonnentag, 2003). A sample item was 'Today I was under time pressure.' Daily time pressure was assessed in the survey after work. Over the five days, the average internal consistency was .89 (range between .85 and .94).

Daily vigour. Daily vigour was measured with four items from the Profile of Mood States (McNair, Lorr, \& Droppleman, 1971). Participants were asked to evaluate how they felt after work. A sample adjective was 'vigorous'. Daily vigour was assessed in the survey after work. Over the five days, the average internal consistency was .91 (range between .90 and .93).

Daily happiness. Daily happiness was measured with four items of the PANAS-X by Watson and Clark (1994). Participants were asked to evaluate how they felt after work. A sample adjective was 'happy'. Daily happiness was assessed in the survey after work. Over the five days, the average internal consistency was .90 (range between .86 and .92).

\section{Confirmatory Factor Analysis}

To examine whether the study variables and the control variable are distinct constructs, we conducted a series of multilevel confirmatory factor analyses using Mplus 7.0 (Muthén \& Muthén, 1998-2015). We centred all item scores relative to each participant's mean item score and used these person-mean centred items as indicators for each construct (Scott et al., 2010). The hypothesized seven-factor model fit the data satisfactorily, $\chi^{2}(278)=553.90, p<.001$, CFI $=0.93$, TLI $=0.92$, RMSEA $=0.05$, SRMR within $=0.05$, SRMR between $=0.00$. All 26 factor load ings were statistically significant $(p<.001)$. Standardized factor loadings were on average .52 for daily vigour, .55 for daily happiness, .58 for daily time pressure, .52 for daily job control, .47 for daily psychological climate, .60 for daily work-life conflict, and .42 for daily work-life enrichment. We compared the hypothesized sevenfactor model with a series of alternative models which are content-wise obvious (e.g., combination of work-life conflict and work-life enrichment, to ensure that the constructs are distinct). The hypothesized model was superior to the best fitting, content-wise obvious six-factor model, $\chi^{2}(284)=698.31$, CFI $=0.90$, TLI $=0.89$, RMSEA $=0.06$, SRMR within $=0.07$, SRMR between $=0.00, \Delta \chi^{2}(6)=144.40, p$ $<.001$, and to a one-factor model with all items loading on a common factor, 
$\chi^{2}(299)=2760.22, \mathrm{CFI}=0.41, \mathrm{TLI}=0.36, \mathrm{RMSEA}=0.15, \mathrm{SRMR}$ within $=0.14$, SRMR between $=0.00, \Delta \chi^{2}(21)=2206.32, p<.001$.

\section{Analysis}

Our data was composed of two levels per person: the person level (Level 2) and the day level (Level 1), with day-level data nested within persons. All of the variables of interest were assessed on day level.

Before conducting analyses of daily relationships between time pressure as well as psychological climate and the work-life variables, we investigated the amount of variation in our study variables attributable to within-person and between-person sources. ICC1 values reflect the percentage of variance in each daily-measured variable which is explained by between-person differences. ICCs ranged between .39 and .60 (Table 1), meaning that $40 \%$ to $61 \%$ of the variance is considered within a person. Hence, the use of multilevel analysis is justified.

We analysed our data with nested multilevel path models using Mplus 7.0 (Muthén \& Muthén, 1998-2015) with Maximum Likelihood estimation. We centred the predictor and control variables at the respective person mean (Hofmann \& Gavin, 1998) so that the effects could be attributed to within-person variation. For the estimation of the indirect effects of the mediation analyses, we used the product-of-coefficients method (Nohe, Michel, \& Sonntag, 2014), to test the significance of the hypothesized mediational effects (Hypotheses 3, 4, 7, \& 8).

\section{Results}

\section{Descriptive Statistics}

Table 1 shows means, standard deviations, average Cronbach's $\alpha$, ICC1 and correlations among the study variables and control variable at the within-person level and at the between-person level (aggregated values of each person were correlated). Notably, all of the within-person correlations of the study variables were statistically significant. These correlations preliminarily indicate that testing our mediation model was justified. 
Table 1: Descriptive statistics and within-individual and between-individual correlations among study variables

\begin{tabular}{|c|c|c|c|c|c|c|c|c|c|c|c|c|c|c|c|c|c|c|}
\hline Variable & $M$ & $S D$ & $\alpha$ & ICC1 & 1 & & 2 & & 3 & & 4 & & 5 & & 6 & & 7 & \\
\hline 1. Time pressure & 2.34 & 1.16 & .89 & .57 & - & & -.21 & ${ }^{* *}$ & -.12 & * & -.17 & ** & -.25 & ** & .43 & $* *$ & -.19 & ** \\
\hline $\begin{array}{l}\text { 2. Psychological } \\
\text { climate }\end{array}$ & 3.96 & 0.94 & .92 & .60 & -.25 & $*$ & - & & .29 & $* *$ & .40 & $* *$ & .23 & ** & -.34 & $* *$ & .26 & ** \\
\hline 3. Vigour & 2.84 & 0.84 & .91 & .42 & -.11 & & .37 & $* *$ & - & & .71 & $* *$ & .26 & $* *$ & -.42 & & .10 & \\
\hline 4. Happiness & 2.81 & 0.88 & .90 & .39 & -.20 & & .47 & $* *$ & .76 & $* *$ & - & & .22 & * & -.37 & $* *$ & .10 & \\
\hline $\begin{array}{l}\text { 5. Work-life } \\
\text { enrichment }\end{array}$ & 2.27 & 0.86 & .78 & .49 & -.25 & $*$ & .23 & * & .24 & * & .24 & * & - & & -.31 & $* *$ & .14 & * \\
\hline $\begin{array}{l}\text { 6. Work-life } \\
\text { conflict }\end{array}$ & 2.17 & 1.07 & .90 & .51 & .51 & $* *$ & -.41 & $* *$ & -.50 & $* *$ & -.47 & $* *$ & -.31 & $* *$ & - & & -.26 & $* *$ \\
\hline 7. Job control & 3.78 & 0.98 & .86 & .52 & -.27 & $* *$ & .27 & $* *$ & .09 & & .06 & & .14 & & .51 & $* *$ & - & \\
\hline
\end{tabular}

Note. The reported $\alpha$ is the average over the five days. Correlations above the diagonal are based on non-averaged data $(n=357)$; correlations below the diagonal are based on withinperson averages $(N=92)$.

${ }^{*} p<.05 .{ }^{* *} p<.01$.

\section{Hypotheses Testing}

We tested our hypotheses with a set of multilevel path models. The processes we were interested in are within-person processes. Therefore, we did not consider the possible between-person-regressions.

We started with a control model. In the control model only, the direct effects of job control on work-life conflict and work-life enrichment were specified besides the correlations between predictor variables, mediator variables, and outcome variables on the within-person level and the correlations between mediator variables and outcome variables on the between-person level. In the second model, the predictor model, we included direct effects of time pressure and psychological climate on both work-life conflict and work-life enrichment. To test the mediation hypotheses, we added vigour and happiness to the model. We specified both a full mediation model and a partial mediation model.

We tested the improvement of each model over the previous one regarding $-2 \times \log$ (lh). Model fit indices are presented in Table 2.

In Hypothesis 1 we proposed that daily time pressure is positively related to daily work-life conflict, in Hypothesis 2 that this demand is negatively related to worklife enrichment. In Hypotheses 5 we proposed that daily psychological climate at work is negatively related to daily work-life conflict and in Hypothesis 6 that it is positively related to work-life enrichment. Results indicate that the model improved by adding the predictor variables to the control model, $\Delta-2 \times \log (\mathrm{lh})=41.94, \Delta d f$ $=4, p<.001, R^{2}$-within (work-life conflict) $=.08, R^{2}$-within (work-life enrichment) $=.07$ (Table 2). Specifically, time pressure was related to work-life conflict $(\gamma=.24$, $S E=.06, p<.01)$ and to work-life enrichment $(\gamma=-0.14, S E=.05, p<.01)$ in the 
Table 2: Fit indices for the nested multilevel path models

\begin{tabular}{lrrrrrrrr}
\hline Model & \multicolumn{1}{c}{$\chi^{2}$} & $d f$ & $\Delta-2 \times \log (\mathrm{lh})(\Delta d f)$ & CFI & TLI & RMSEA & $\begin{array}{r}\text { SRMR } \\
\text { within }\end{array}$ & $\begin{array}{r}\text { SRMR } \\
\text { between }\end{array}$ \\
\hline Control model & 136.853 & 18 & - & 0.707 & 0.561 & 0.136 & 0.148 & 0.262 \\
Predictor model & 94.918 & 14 & $41.935(4)$ & 0.801 & 0.615 & 0.127 & 0.127 & 0.261 \\
Full mediation model & 48.255 & 10 & $46.663(4)$ & 0.906 & 0.745 & 0.104 & 0.056 & 0.262 \\
Partial mediation model & 22.255 & 6 & $26.000(4)$ & 0.960 & 0.820 & 0.087 & 0.014 & 0.262 \\
\hline
\end{tabular}

Note. $N=92$ persons and $n=357$ days. All models were compared with the previous one. All $\Delta-2 \times \log ($ Ih) are significant at $p<.001$.

hypothesized direction. As hypothesized, psychological climate was negatively related to work-life conflict $(\gamma=-0.20, S E=.08, p<.01)$ and positively related to worklife enrichment $(\gamma=0.23, S E=.06, p<.01)$. On days, when employees experience less psychological climate and more time pressure, they experience more conflicts between work and home domains and on days when employees experience more psychological climate and less time pressure, they feel more enriched at home by their work.

Job control was unrelated to both work-life variables both in the control and the predictor model (Table 3).

Table 3: Main effects of job control (control variable, Model 1), time pressure, and psychological climate (Model 2) on work-life conflict as well as on work-life enrichment tested via Mplus multilevel path analysis

\begin{tabular}{|c|c|c|c|c|c|c|c|}
\hline \multirow[b]{2}{*}{ DV } & \multirow[b]{2}{*}{$\mathrm{IV} / \mathrm{CV}$} & \multicolumn{3}{|c|}{$\begin{array}{l}\text { Model } 1 \\
\text { control variable }\end{array}$} & \multicolumn{3}{|c|}{$\begin{array}{l}\text { Model } 2 \\
\text { main effects }\end{array}$} \\
\hline & & Estimate & $S E$ & $t$ & Estimate & $S E$ & $t$ \\
\hline$\overline{W L C}$ & job control & -0.114 & 0.068 & -1.667 & -0.081 & 0.068 & -1.191 \\
\hline WLC & time pressure & & & & 0.240 & 0.059 & $4.041^{* *}$ \\
\hline WLC & psychological climate & & & & -0.203 & 0.078 & $-2.604 * *$ \\
\hline WLE & job control & 0.034 & 0.056 & 0.617 & -0.012 & 0.055 & -0.215 \\
\hline WLE & time pressure & & & & -0.135 & 0.048 & $-2.792 * *$ \\
\hline WLE & psychological climate & & & & 0.231 & 0.064 & $3.627 * *$ \\
\hline
\end{tabular}

Note. $N=92$ persons and $n=357$ days. $\mathrm{DV}=$ dependent variable. IV = independent variable. $\mathrm{CV}=$ control variable. $\mathrm{WLC}=$ work-life conflict. $\mathrm{WLE}=$ work-life enrichment.

${ }^{*} p<.05 .{ }^{* *} p<.01$.

\section{Hypotheses Testing - Mediation}

Hypothesis 3 and 7 proposed a mood-path, meaning happiness, to be a mediator in the presented relationships. Hypothesis 4 and 8 proposed an energy-path, meaning vigour, to be a mediator between work characteristics and home outcomes. To test the mediation hypotheses via path analysis, we first compared a full-mediation model with a partial-mediation model. Specifically, we compared a mediation mod- 
el including direct paths between psychological climate and time pressure and work-life variables (i.e., partial-mediation model) with a mediation model without such direct paths (i.e., full-mediation model). Because the model with a direct path showed a better fit to the data $(\Delta-2 \times \log (\mathrm{lh})=26.00 ; \Delta \mathrm{df}=4 ; p<.001$; Table 2$)$, we retained this partial-mediation model for testing Hypothesis 3, 4, 7 and 8 . To quantify the explained variance we report the $R^{2}$-within values put out by Mplus 7.0 (Muthén \& Muthén, 1998-2015): $R^{2}$-within (work-life conflict) $=.19, R^{2}$-within (work-life enrichment) $=.13, R^{2}$-within (happiness) $=.06, R^{2}$-within $($ vigour $)=.05$. All of the mediation paths are presented in Table 4 .

Table 4: Direct effects between dependent, independent and mediator variables tested via Mplus path analysis

\begin{tabular}{|c|c|c|c|c|c|c|c|c|c|c|c|c|}
\hline \multirow{3}{*}{$\begin{array}{l}\text { DV } \\
\text { WLC }\end{array}$} & \multirow{3}{*}{$\begin{array}{l}\text { IV } \\
\text { time } \\
\text { pressure }\end{array}$} & \multirow{3}{*}{$\begin{array}{l}\begin{array}{l}\text { Medi- } \\
\text { ator }\end{array} \\
\text { happi- } \\
\text { ness }\end{array}$} & \multirow{2}{*}{\multicolumn{2}{|c|}{$\begin{array}{c}\mathrm{IV} \rightarrow \mathrm{DV} \\
b_{1}(S E)\end{array}$}} & \multirow{2}{*}{\multicolumn{2}{|c|}{$\begin{array}{c}\mathrm{IV} \rightarrow \text { Med } \\
b_{2}(S E)\end{array}$}} & \multirow{2}{*}{\multicolumn{2}{|c|}{$\begin{array}{c}\text { Med } \rightarrow \text { DV } \\
b_{3}(S E)\end{array}$}} & \multicolumn{4}{|c|}{ Indirect effect } \\
\hline & & & & & & & & & \multicolumn{2}{|c|}{$b_{4}(S E)$} & \multirow{2}{*}{$\begin{array}{c}z \\
0.20\end{array}$} & \multirow{2}{*}{$\begin{array}{c}95 \% \mathrm{Cl} \\
{[-0.01,0.02]}\end{array}$} \\
\hline & & & 0.17 & ${ }^{* *} \quad(0.06)$ & $-0.12^{*}$ & $(0.06)$ & -0.02 & $(0.08)$ & 0.00 & $(0.01)$ & & \\
\hline WLC & $\begin{array}{l}\text { psychological } \\
\text { climate }\end{array}$ & $\begin{array}{l}\text { happi- } \\
\text { ness }\end{array}$ & -0.15 & $+\quad(0.08)$ & $0.27^{* *}$ & $(0.07)$ & -0.02 & $(0.08)$ & -0.00 & $(0.02)$ & -0.20 & {$[-0.04,0.03]$} \\
\hline WLC & $\begin{array}{l}\text { time } \\
\text { pressure }\end{array}$ & vigour & 0.17 & ${ }^{* *} \quad(0.06)$ & $-0.17^{* *}$ & $(0.05)$ & $-0.38^{* *}$ & $(0.09)$ & 0.07 & $(0.03)$ & $2.66^{* *}$ & {$[0.03,0.11]$} \\
\hline WLC & $\begin{array}{l}\text { psychological } \\
\text { climate }\end{array}$ & vigour & -0.15 & $(0.08)$ & $0.15^{*}$ & $(0.07)$ & $-0.38^{* *}$ & $(0.09)$ & -0.06 & $(0.03)$ & $-2.01 *$ & {$[-0.10,-0.01]$} \\
\hline WLE & $\begin{array}{l}\text { time } \\
\text { pressure }\end{array}$ & $\begin{array}{l}\text { happi- } \\
\text { ness }\end{array}$ & -0.09 & $(0.05)$ & $-0.12^{*}$ & $(0.06)$ & -0.01 & $(0.07)$ & 0.00 & $(0.01)$ & 0.14 & {$[-0.01,0.01]$} \\
\hline WLE & $\begin{array}{l}\text { psychological } \\
\text { climate }\end{array}$ & $\begin{array}{l}\text { happi- } \\
\text { ness }\end{array}$ & 0.20 & ** $\quad(0.06)$ & $0.27^{* *}$ & $(0.07)$ & -0.01 & $(0.07)$ & -0.01 & $(0.07)$ & -0.15 & {$[-0.12,0.10]$} \\
\hline WLE & $\begin{array}{l}\text { time } \\
\text { pressure }\end{array}$ & vigour & -0.09 & $(0.05)$ & $-0.17^{* *}$ & $(0.05)$ & $0.24^{* *}$ & $(0.07)$ & -0.04 & $(0.02)$ & $-2.40^{*}$ & {$[-0.07,-0.01]$} \\
\hline WLE & $\begin{array}{l}\text { psychological } \\
\text { climate }\end{array}$ & vigour & 0.20 & ** $\quad(0.06)$ & $0.15 *$ & $(0.07)$ & $0.24^{* *}$ & $(0.07)$ & 0.04 & $(0.02)$ & 1.89 & {$[0.01,0.07]$} \\
\hline
\end{tabular}

Note. $\mathrm{DV}=$ dependent variable. IV = independent variable. Med $=$ Mediator. $\mathrm{WLC}=$ work-life conflict. WLE $=$ work-life enrichment.

${ }^{*} p<.05 .{ }^{* *} p<.01$.

Only vigour mediated between work and home domain. To quantify the indirect effect of the energy-path, we used the product-of-coefficients method (i. e. multiplying the coefficient of the path between independent variable and mediator by the coefficient of the path between mediator and dependent variable; cf. MacKinnon, Lockwood, Hoffman, West, \& Sheets, 2002). Analysis resulted in a significant indirect effect for vigour in the relationship between time pressure and work-life conflict $(b=.07, S E=0.03, z=2.66, p<.01,95 \%$ CI $[0.03,0.11])$, as well as the relationship between time pressure and work-life enrichment $(b=-.04, S E=0.02, z$ $=-2.40, p<.05,95 \%$ CI $[-0.07,-0.01])$. Results indicate a significant indirect effect for vigour in the relationship between psychological climate and work-life con- 
flict $(b=-.06, S E=0.03 z=-2.01, p<.05,95 \%$ CI $[-0.10,-0.01])$. The indirect effect for vigour in the relationship between psychological climate and work-life enrichment did not reach statistical significance $(b=.04, S E=0.02, z=1.89, p>.05$, $95 \%$ CI $[0.01,0.07])$. Taken together, daily vigour after work functions as a partial mediator in the daily relationship between daily time pressure and daily work-life conflict and enrichment as well as between daily psychological climate and daily work-life conflict.

\section{Discussion}

We conducted a daily diary study to enlighten the daily relationships between time pressure and psychological climate on the one hand and work-life conflict and work-life enrichment on the other hand. Results revealed that daily time pressure increased work-life conflict and decreased work-life enrichment. Daily psychological climate was negatively related to work-life conflict and positively related to work-life enrichment. Job control was not related to the outcomes. Results of the mediation analyses revealed evidence for the energy-path, as vigour was found as the mediating process. There was no evidence for a mood-path as the affective state happiness was not confirmed as a mediator.

In line with research on demands at work as predictors of the work-life interface (Michel et al., 2011), we found that time pressure is an important work demand in the interface between work and private life on the daily level. Research has shown, that time pressure is detrimental for both negative and positive home outcomes (Sonnentag \& Bayer, 2005; Stiglbauer, 2017). Our study goes conform with these results. On a daily basis, time pressure is strongly associated with work-life conflict and enrichment. Our results are in line with the view that time pressure is a detrimental work condition with negative consequences even beyond the workplace. Having too many work tasks for the time available at work, employees use up their self-regulating resources (Meijman \& Mulder, 1998), and are exhausted when they leave work. At home, they lack the energy for the engagement in family life and for their hobbies. Employees may even ruminate on the work tasks in the after-hours. In this way, time pressure increases conflicts between work and private life and impedes enrichment between work and private life.

In line with research on the benefits of psychological climate at work (Kühnel et al., 2012; Xanthopoulou et al., 2012) we found that daily psychological climate is positively related to daily work-life enrichment and negatively related to daily work-life conflict. On days when employees experience a higher level of psychological climate, they leave work more vigorous. The energy resources make it easier to engage in private life. Consequently, for organizations, it is important to create a positive psychological climate in work groups so that employees perceive their workgroup positively and leave work full of energy. Having enough energy after work to engage in private life does not only mean that employees are better family members. They 
also have energy for recovery and as such to maintain and accumulate resources (Hobfoll, 2001). Future research could create and evaluate work-related interventions which foster a positive perception of the workgroup and social environment characteristics at work and as such help employees balancing their work and private life.

Greenhaus and Powell (2006) hypothesize that the association between work resources and home outcomes are mediated by positive affective states. Our study is one of the first studies which explores both hedonic and eudaimonic well-being as mediators between work and home variables. In line with the self-regulation approach, we found evidence for the energy-path. On a daily basis vigour (eudaimonic well-being) mediates the association between work conditions and work-life variables, whereas happiness (hedonic well-being) does not mediate the relationship. On days, when employees leave work in an energetic, vigorous state, their self-regulation resource (Baumeister et al., 1994) is not depleted. Daily demands and hassles are more easily handled. As such, life is more enriched and less conflicted by their work. The mood-path which refers to the positive impact through positive emotions suggested by the broaden-and-build-theory (Fredrickson, 1998) could not be confirmed in our diary study, even though mood is widely discussed as an underlying mechanism in the literature on the work-life interface (e. g. Williams \& Alliger, 1994). Maybe the broaden-and-build process is a process which does not unfold within one day but unfolds over longer time periods as resources may need to achieve a certain level to unfold their positive effects on positive emotions.

With regard to our control variable job control, we did not find positive nor negative relationships with the outcomes. There is a lot of evidence for job control being an important work resource (Butler et al., 2005; Mauno \& Rantanen, 2013; Nahrgang, Morgeson, \& Hofmann, 2011; Treiber \& Davis, 2012). However, there is also recent research showing that flexible work-times, which is one aspect of job control in many jobs, are detrimental for need for recovery (Biron \& van Veldhoven, 2016). Consequently, particularly when considering its effects on the worklife interface, job control may work both as a resource as well as a demand (Langfred \& Moye, 2004). Maybe the role of job control, both positively and negatively, unfolds rather in the long run than on a daily basis. In a longitudinal study over four years, Armon, Melamed, and Shirom (2012) found an increase in vigour when job control was increased. Nonetheless, it is reasonable to further examine job control also on a daily basis, as we found the construct to vary within persons. Moreover, work conditions should be further examined, and circumstances discovered under which job control is rather beneficial and under which circumstances job control is rather detrimental for employees.

In sum, the findings highlight that daily time pressure and psychological climate are important antecedents of how we experience our leisure time every single day and that after work vigour as an indicator of self-regulatory resources is a mediating 
mechanism. Our findings are in line with both the work-home resources model (ten Brummelhuis \& Bakker, 2012) and the Model of Work-Family Enrichment (Greenhaus \& Powell, 2006).

\section{Limitations and Implications}

The design employed in this study has several advantages but also holds limitations. The within-person research design permitted an examination of the link between work and private life over relatively short periods of time and allowed us to demonstrate predictable daily variation in the work-life experience.

Nonexperimental studies may hold the problem of endogeneity which concerns the matter of causality. The problem of endogeneity includes omitted variables, omitted selection, simultaneity, common-method variance, and measurement error (Antonakis, Bendahan, Jacquart, \& Lalive, 2010). A causal effect is achieved when y follows $\mathrm{x}$, when $\mathrm{y}$ changes as $\mathrm{x}$ changes and other possible causes are eliminated (Holland, 1986; Kenny, 1979). Our design to a certain degree reduces the problem of endogeneity, as we separated measurements of predictor and outcome variables by time. We measured our predictor variables in the afternoon after work, while the outcome variables were measured in the evening before going to bed. However, as our study is a nonexperimental study, we could not eliminate other possible causes in the change of the outcome variables, as one can do in an experiment. Thus, our study design cannot compensate for omitted variables and omitted selection. However, as we estimated both outcomes in the same structural equation model, this procedure should have alleviated the problem of endogeneity (Wooldridge, 2015). The use of self-reports may have led to bias because of common method variance (Podsakoff \& Organ, 1986), but this type of bias is less likely in multi-measurement studies like ours (Podsakoff \& Organ, 1986). Nevertheless, in future studies, other experimental designs or field study designs including partner ratings for the worklife variables and colleague or supervisor ratings for work conditions would be advisable.

The fact that we only used two measurement points may hold a retrospective bias (Reis \& Gable, 2000) because a longer period of time over the day was evaluated. An event sampling design, with which work characteristics are measured more often during the workday, would sharpen the knowledge about the mechanisms between work conditions and home outcomes. However, such a design is also associated with much more costs for participants that have to be balanced when implementing a daily diary design.

In future studies on the work-life interface, other daily demands and daily resources may be considered. For example, positive leadership behaviour (Kelloway, Weigand, McKee, \& Das, 2013) or appreciation (Stocker, Jacobshagen, Semmer, \& Annen, 2010) at work may be important work resources concerning the social work-environment, apart from psychological climate. Work role conflict (Michel et al., 2011) 
and interpersonal emotional demands such as sensitivity requirements (requirement to be sensitive and consider the emotions of others; Zapf, 2002) may be important social work stressors, which should be taken into account in future studies. Furthermore, research on the work-life interface should also include the examination of personality (Michel et al., 2011). We assumed that personality does not change on a daily level and thus did not include personality in our study. Cross-level interactions for personality facets as for example internal locus of control (the extent to which individuals feel outcomes are caused by the self; Rotter, 1966) or segmentation preferences between work and home domain (Kreiner, 2006), though, may be considered.

We did not ask which kinds of activities individuals pursued in the evening. Some activities (e.g., caring for children and elderly, advanced education, sports) might need more self-regulation resources than others. Consequently, participants might evaluate work-life conflict and enrichment differently for different after work activities they pursued.

It might appear, that our study concerns a very specific type of workers since participants were working in municipal administration. Though, jobs the participants fulfilled were quite diverse as they worked for example in administration, in the field of construction, architecture, and measurement, or in the social and educational sector.

Sonnentag and Bayer (2005) suggested using handheld computers for data collection that allow for the recording of time stamps when specific items are completed. We used portable devices to collect our data which allowed for the recording of time stamps. Thereby we knew which questionnaires were answered at what time and we could exclude participants who did not fill out the surveys according to instruction.

With respect to practical implications, our findings underscore the importance of vigour after work as an antecedent of positive home outcomes. Therefore, employees should be encouraged to organize their work better so that self-regulating resources are not used up for workplace organization, but for the work itself. Managers should encourage their employees to plan work proactively and to manage time effectively and consequently mitigate time pressure. Further, to foster psychological climate, managers could support regular team activities. Future research should focus on interventions taking both workplace organization and fostering of a positive psychological climate into account. Employees could profit from reduction of workplace strain which potentially results in long-term well-being and health (Geurts \& Sonnentag, 2006). 


\section{References}

Antonakis, J., Bendahan, S., Jacquart, P., \& Lalive, R. (2010). On making causal claims: A review and recommendations. The Leadership Quarterly, 21(6), 1086-1120. doi:10.1016/j.leaqua. 2010.10.010

Armon, G., Melamed, S., \& Shirom, A. (2012). The relationship of the Job Demands-ControlSupport Model with vigor across time: Testing for reciprocality. Applied Psychology: Health and Well-Being, 4(3), 276-298. doi:10.1111/j.1758-0854.2012.01074.x

Bakker, A. B., Demerouti, E., \& Dollard, M. F. (2008). How job demands affect partners' experience of exhaustion: integrating work-family conflict and crossover theory. Journal of Applied Psychology, 93(4), 901-911. doi: 10.1037/0021-9010.93.4.901

Baumeister, R. E, Heatherton, T. E, \& Tice, D. M. (1994). Losing control: How and why people fail at self-regulation. San Diego, CA: Academic Press.

Beal, D. J., Weiss, H. M., Barros, E., \& MacDermid, S. M. (2005). An episodic process model of affective influences on performance. Journal of Applied Psychology, 90(6), 1054-1068. doi: 10.1037/0021-9010.90.6.1054

Biron, M., \& van Veldhoven, M. (2016). When control becomes a liability rather than an asset: Comparing home and office days among part-time teleworkers. Journal of Organizational Behavior, 37(8), 1317-1337. doi:10.1002/job.2106

Butler, A. B., Grzywacz, J. G., Bass, B. L., \& Linney, K. D. (2005). Extending the demands-control model: A daily diary study of job characteristics, work-family conflict and work-family facilitation. Journal of Occupational and Organizational Psychology, 78(2), 155-169. doi: 10.1348/096317905X40097

Chen, Z., Powell, G. N., \& Cui, W. (2014). Dynamics of the relationships among work and family resource gain and loss, enrichment, and conflict over time. Journal of Vocational Behavior, 84(3), 293-302. doi:10.1016/j.jvb.2014.02.006

Daniel, S., \& Sonnentag, S. (2014). Work to non-work enrichment: The mediating roles of positive affect and positive work reflection. Work \& Stress, 28(1), 49-66. doi: 10.1080/02678373.2 013.872706

Deci, E. L., \& Ryan, R. M. (1985). Intrinsic motivation and self-determination in human behavior. New York, NY: Plenum Press.

Demerouti, E., Kattenbach, R., \& Nachreiner, F. (2003). Flexible working times: Consequences on employees' burnout, work-nonwork conflict and performance. Shiftwork International Newsletter, 20, 61.

Eurostat (2016). Household characteristics by type of household [Data file]. Retrieved from http:// appsso.eurostat.ec.europa.eu/nui/show.do?dataset=hbs_car_t313\&lang=en

Fisher, G. G., Bulger, C. A., \& Smith, C. S. (2009). Beyond work and family: A measure of work/ nonwork interference and enhancement. Journal of Occupational Health Psychology, 14(4), 441-456. doi:10.1037/a0016737

Frese, M. (1985). Stress at work and psychosomatic complaints: A causal interpretation. Journal of Applied Psychology, 70(2), 314-328. doi:10.1037/0021-9010.70.2.314

Fredrickson, B.L. (1998). What good are positive emotions? Review of General Psychology, 2(3), 300-319. doi:10.1037/1089-2680.2.3.300 
Garst, H., Frese, M., \& Molenaar, P. C. M. (2000). The temporal factor of change in stressorstrain relationships: A growth curve model on a longitudinal study in East Germany. Journal of Applied Psychology, 85(3), 417-438. doi:10.1037/0021-9010.85.3.417

Gatrell, C. J., Burnett, S. B., Cooper, C. L., \& Sparrow, P. (2013). Work-life balance and parenthood: A comparative review of definitions, equity and enrichment. International Journal of Management Reviews, 15(3), 300-316. doi:10.1111/j.1468-2370.2012.00341.x

Geurts, S. A., \& Sonnentag, S. (2006). Recovery as an explanatory mechanism in the relation between acute stress reactions and chronic health impairment. Scandinavian Journal of Work, Environment \& Health, 32 (6, special issue), 482-492.

Grawitch, M. J., \& Barber, L. K. (2010). Work flexibility or nonwork support? Theoretical and empirical distinctions for work-life initiatives. Consulting Psychology Journal: Practice and Research, 62(3), 169-188. doi:10.1037/a0020591

Greenhaus, J. H., \& Beutell, N. J. (1985). Sources and conflict between work and family roles. The Academy of Management Review, 10(1), 76-88. doi:10.2307/258214

Greenhaus, J. H., \& Powell, G. N. (2006). When work and family are allies: A theory of workfamily enrichment. The Academy of Management Review, 31(1), 72-92. doi:10.2307/20159186

Hackman, J. R., \& Oldham, G. R. (1976). Motivation through the design of work: Test of a theory. Organizational Behavior and Human Performance, 16(2), 250-279. doi: 10.1016/0030-5073(76)90016-7

Hahn, V. C., Frese, M., Binnewies, C., \& Schmitt, A. (2012). Happy and proactive? The role of hedonic and eudaimonic well-being in business owners' personal initiative. Entrepreneurship Theory and Practice, 36(1), 97-114. doi:10.1111/j.1540-6520.2011.00490.x

Halbesleben, J. B. (2006). Sources of social support and burnout: A meta-analytic test of the conservation of resources model. Journal of Applied Psychology, 91(5), 1134-1145. doi: 10.1037/0021-9010.91.5.1134

Hobfoll, S. E. (2001). The influence of culture, community, and the nested-self in the stress process: Advancing Conservation of Resources theory. Applied Psychology: An International Review, 50(3), 337-370. doi:10.1111/1464-0597.00062

Höge, T. (2009). When work strain transcends psychological boundaries: An inquiry into the relationship between time pressure, irritation, work-family conflict and psychosomatic complaints. Stress and Health, 25(1), 41-51. doi:10.1002/smi.1226

Hofmann, D. A., \& Gavin, M. B. (1998). Centering decisions in hierarchical linear models: Implications for research in organizations. Journal of Management, 24(5), 623-641. doi: $10.1177 / 014920639802400504$

Holland, P. W. (1986). Statistics and causal inference. Journal of the American Statistical Association, 81(396), 945-960.

James, L. R., \& Jones, A. P. (1974). Organizational climate: A review of theory and research. Psychological Bulletin, 81(12), 1096-1112. doi:10.1037/h0037511

Jones, A. P., \& James, L. R. (1979). Psychological climate: Dimensions and relationships of individual and aggregated work environment perceptions. Organizational Behavior \& Human Performance, 23(2), 201-250. doi:10.1016/0030-5073(79)90056-4

Karasek, R. (1979). Job demands, job decision latitude, and mental strain: Implications for job redesign. Administrative Science Quarterly, 24, 285-308. doi:10.2307/2392498 
Keeney, J., Boyd, E. M., Sinha, R., Westring, A. F., \& Ryan, A. M. (2013). From "work-family" to "work-life": Broadening our conceptualization and measurement. Journal of Vocational Behavior, 82(3), 221-237. doi:10.1016/j.jvb.2013.01.005

Kelloway, E. K., Weigand, H., McKee, M. C., \& Das, H. (2013). Positive leadership and employee well-being. Journal of Leadership and Organizational Studies, 20(1), 107-117. doi: $10.1177 / 1548051812465892$

Kenny, D. A. (1979). Correlation and causality. New York: Wiley-Interscience.

Kreiner, G. E. (2006). Consequences of Work-Home Segmentation or Integration: A Person-Environment Fit Perspective. Journal of Organizational Behavior, 27(4), 485-507. doi:10.1002/ job.386

Kühnel, J., Sonnentag, S., \& Bledow, R. (2012). Resources and time pressure as day-level antecedents of work engagement. Journal of Occupational and Organizational Psychology, 85(1), 181-198. doi:10.1111/j.2044-8325.2011.02022.x

Langfred, C. W., \& Moye, N. A. (2004). Effects of task autonomy on performance: An extended model considering motivational, informational, and structural mechanisms. Journal of Applied Psychology, 89(6), 934-945. doi:10.1037/0021-9010.89.6.934

Mauno, S., De Cuyper, N., Kinnunen, U., Ruokolainen, M., Rantanen, J., \& Mäkikangas, A. (2015). The prospective effects of work-family conflict and enrichment on job exhaustion and turnover intentions: Comparing long-term temporary vs. permanent workers across three waves. Work \& Stress, 29(1), 75-94. doi:10.1080/02678373.2014.1003997

Mauno, S., \& Rantanen, M. (2013). Contextual and dispositional coping resources as predictors of work-family conflict and enrichment: which of these resources or their combinations are the most beneficial? Journal of Family and Economic Issues, 34(1), 87-104. doi:10.1007/ s10834-012-9306-3

MacKinnon, D. P., Lockwood, C. M., Hoffman, J. M., West, S. G., \& Sheets, V. (2002). A comparison of methods to test mediation and other intervening variable effects. Psychological Methods, 7(1), 83-104. doi:10.1037/1082-989x.7.1.83

Martínez-Martí, M. L., \& Ruch, W. (2017). The relationship between orientations to happiness and job satisfaction one year later in a representative sample of employees in Switzerland. Journal of Happiness Studies, 18(1), 1-15. doi:10.1007/s10902-016-9714-4

McNair, D., Lorr, M., \& Droppleman, L. (1971). Manual for the profile of mood states. San Diego, CA: Educational and Industrial Testing Service.

McNall, L. A., Scott, L. D., \& Nicklin, J. M. (2015). Do positive affectivity and boundary preferences matter for work-family enrichment? A study of human service workers. Journal of Occupational Health Psychology, 20(1), 93-104. doi:10.1037/a0038165

Meijman, T. E, \& Mulder, G. (1998). Psychological aspects of workload. In P. J. D. Drenth, \& H. Thierry (Eds.), Handbook of work and organizational psychology: Work psychology (Vol. 2, pp. 5-33). Hove, U.K.: Psychology Press.

Melamed, S., Kushnir, T., \& Meir, E. I. (1991). Attenuating the impact of job demands: Additive and interactive effects of perceived control and social support. Journal of Vocational Behavior, 39(1), 40-53. doi:10.1016/0001-8791(91)90003-5

Michel, J. S., Kotrba, L. M., Mitchelson, J. K., Clark, M. A., \& Baltes, B. B. (2011). Antecedents of work-family conflict: A meta-analytic review. Journal of Organizational Behavior, 32(5), 689-725. doi:10.1002/job.695 
Moazami-Goodarzi, A., Nurmi, J., Mauno, S., \& Rantanen, J. (2015). Cross-lagged relations between work-family enrichment, vigor at work, and core self-evaluations: A three-wave study. Journal of Business and Psychology, 30(3), 473-482. doi:10.1007/s10869-014-9376-3

Muraven, M., \& Baumeister, R. F. (2000). Self-regulation and depletion of limited resources: Does self-control resemble a muscle?. Psychological Bulletin, 126(2), 247-259. doi: 10.1037/0033-2909.126.2.247

Muthén, L. K. \& Muthén, B. O. (1998-2015). Mplus User's Guide (7th ed.). Los Angeles, CA: Muthén \& Muthén.

Nahrgang, J. D., Morgeson, F. P., \& Hofmann, D. A. (2011). Safety at work: A meta-analytic investigation of the link between job demands, job resources, burnout, engagement, and safety outcomes. Journal of Applied Psychology, 96(1), 71-94. doi:10.1037/a0021484

Nohe, C., Michel, A. \& Sonntag, K. (2014). Family-work conflict and job performance: A diary study of boundary conditions and mechanisms. Journal of Organizational Behavior, 35(3), 339357. doi:10.1002/job. 1878

Ohly, S., Sonnentag, S., Niessen, C., \& Zapf, D. (2010). Diary studies in organizational research: An introduction and some practical recommendations. Journal of Personnel Psychology, 9(2), 79-93. doi:10.1027/1866-5888/a000009

Parasuraman, S., \& Simmers, C. (2001). Type of employment, work-family conflict and well-being: A comparative study. Journal of Organizational Behavior, 22(5), 551-568. doi:10.1002/job. 102

Podsakoff, P. M., \& Organ, D. W. (1986). Self-reports in organizational research: Problems and prospects. Journal of Management, 12(4), 531-544. doi:10.1177/014920638601200408

Reis, H. T., \& Gable, S. L. (2000). Event-sampling and other methods for studying everyday experience. In H. T. Reis \& C. M. Judd (Eds.), Handbook of research methods in social and personality psychology (pp. 190-222). New York, NY: Cambridge University Press.

Rotter, J. B. (1966). Generalized expectancies for internal versus external control of reinforcement. Psychological Monographs: General and Applied, 80(1), 1-28. doi:10.1037/h0092976

Ryan, R.M. \& Deci, E.L. (2001). On happiness and human potentials: A review of research on hedonic and eudaimonic well-being. Annual Review of Psychology, 52(1), 141-166. doi: 10.1146/annurev.psych.52.1.141

Schaufeli, W. B., \& Taris, T. W. (2014). A critical review of the job demands-resources model: Implications for improving work and health. In G. Bauer, \& O. Hämmig (Eds.), Bridging occupational, organizational and public health (pp. 43-68). Amsterdam: Springer Netherlands.

Scott, B. A., Colquitt, J. A., Paddock, E. L., \& Judge, T. A. (2010). A daily investigation of the role of manager empathy on employee well-being. Organizational Behavior and Human Decision Processes, 113(2), 127-140. doi:10.1016/j.obhdp.2010.08.001

Seiger, C. P., \& Wiese, B. S. (2009). Social support from work and family domains as an antecedent or moderator of work-family conflicts?. Journal of Vocational Behavior, 75(1), 26-37. doi:10.1016/j.jvb.2009.03.001

Semmer, N. (1984). Streßbezogene Tätigkeitsanalyse [Stress-oriented task-analysis]. Weinheim: Beltz.

Semmer, N. K., Zapf, D., \& Dunckel, H. (1999). Instrument zur Stressbezogenen Tätigkeitsanalyse ISTA [Instrument for stress-oriented task-analysis (ISTA)]. In H. Dunckel (Ed.), Handbuch psychologischer Arbeitsanalyseverfahren (pp. 179-204). Zürich, Switzerland: vdf Hochschulverlag an der ETH. 
Semmer, N., Zapf, D., \& Greif, S. (1996). "Shared job strain": A new approach for assessing the validity of job stress measurements. Journal of Occupational and Organizational Psychology, 69(3), 293-310. doi:10.1111/j.2044-8325.1996.tb00616.x

Sonnentag, S. (2003). Recovery, work engagement, and proactive behavior: a new look at the interface between nonwork and work. Journal of Applied Psychology, 88(3), 518-528. doi: 10.1037/0021-9010.88.3.518

Sonnentag, S., \& Bayer, U. (2005). Switching off mentally: Predictors and consequences of psychological detachment from work during off-job time. Journal of Occupational Health Psychology, 10(4), 393-414. doi:10.1037/1076-8998.10.4.393

Stiglbauer, B. (2017). Under what conditions does job control moderate the relationship between time pressure and employee well-being? Investigating the role of match and personal control beliefs. Journal of Organizational Behavior, 38(5), 730-748. doi.:10.1002/job.2165

Stocker, D., Jacobshagen, N., Semmer, N. K., \& Annen, H. (2010). Appreciation at work in the Swiss armed forces. Swiss Journal of Psychology, 69(2), 117-124. doi:10.1024/1421-0185/ a000013

ten Brummelhuis, L. L., \& Bakker, A. B. (2012). A resource perspective on the work-home interface: The work-home resources model. American Psychologist, 67(7), 545-556. doi:10.1037/ a0027974

Treiber, L. A., \& Davis, S. N. (2012). The role of 'workplace family' support on worker health, exhaustion and pain. Community, Work \& Family, 15(1), 1-27. doi:10.1080/13668803.2011.5 80123

United States Census Bureau. (2015). America's families and living arrangements: 2015 [Data file]. Retrieved from https://www.census.gov/data/tables/2015/demo/families/cps-2015.html

Voydanoff, P. (2001). Incorporating community into work and family research: A review of basic relationships. Human Relations, 54(12), 1609-1637. doi:10.1177/00187267015412003

Voydanoff, P. (2005). Toward a conceptualization of perceived work-family fit and balance: A demands and resources approach. Journal of Marriage and Family, 67(4), 822-836. doi:10.1111/j. 1741-3737.2005.00178.x

Watson, D., \& Clark, L. A. (1994). The PANAS-X: Manual for the positive and negative affect schedule-expanded form. Ames, IA: The University of Iowa.

Williams, K. J., \& Alliger, G. M. (1994). Role stressors, mood spillover, and perceptions of workfamily conflict in employed parents. Academy of Management Journal, 37(4), 837-868. doi: $10.2307 / 256602$

Wooldridge, J. M. (2015). Introductory econometrics: A modern approach (4th ed.). Mason, OH: South-Wstern Cengage Learning.

Xanthopoulou, D., Bakker, A. B., Demerouti, E., \& Schaufeli, W. B. (2009). Work engagement and financial returns: A diary study on the role of job and personal resources. Journal of Occupational and Organizational Psychology, 82(1), 183-200. doi:10.1348/096317908X285633

Xanthopoulou, D., Bakker, A. B., Demerouti, E., \& Schaufeli, W. B. (2012). A diary study on the happy worker: How job resources relate to positive emotions and personal resources. European Journal of Work and Organizational Psychology, 21(4), 489-517. doi:10.1080/1359432X. 2011.584386

Zapf, D. (1993). Stress-oriented analysis of computerized office work. European Work and Organizational Psychologist, 3(2), 85-100. doi: 10.1080/09602009308408580 
Zapf, D. (2002). Emotion work and psychological well-being: A review of the literature and some conceptual considerations. Human Resource Management Review, 12(2), 237-268. doi:10.1016/ S1053-4822(02)00048-7

\section{Global Law for Global Business}

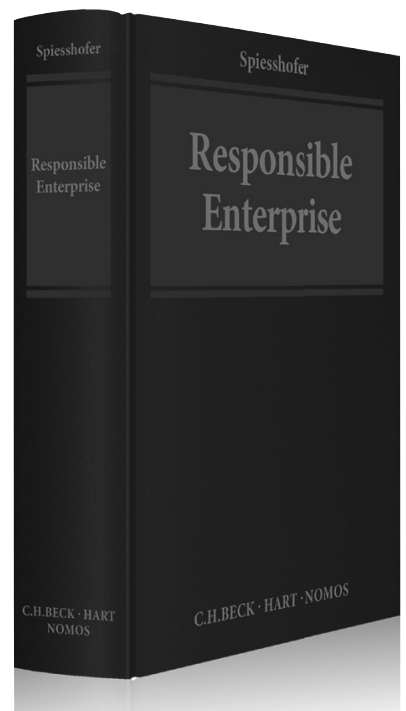

\section{Responsible Enterprise}

By RAin Dr. Birgit Spießhofer, M.C.J. (NYU)

2018, 609 pp., hc., € 220.00

ISBN 978-3-8487-4557-9

eISBN 978-3-8452-8810-9

nomos-shop.de/30776

This fundamental work analyses the great variety of normative processes encompassed by the term 'Corporate Social Responsibility' (CSR) and subjects them to a systematic and critical examination. Domestic and supranational legislation, international law and transnational private law instruments supplemented and superseded by soft law and informal steering by private and public organisations - are the 'smart mix' from which a global order for enterprise responsibility is emerging.

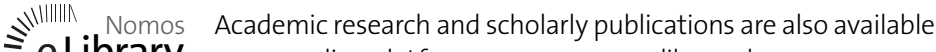 ミ e Library on our online platform: www.nomos-elibrary.de}

